\title{
PENGARUH MODEL PEMBELAJARAN INQUIRYTERHADAP HASIL BELAJAR SISWA PADA MATERI POKOK SUHU KALOR DAN PERPINDAHAN KALOR KELAS X SEMESTERII SMA NEGERI 5 MEDAN T.P. 2014/2015
}

\author{
Rano Karno Nainggolan dan Nurdin Siregar \\ Jurusan Fisika FMIPA Universitas Negeri Medan \\ Jalan Willem Iskandar Pasar V Medan, Sumatera Utara \\ ranokarno.nainggolan@gmail.com
}

\begin{abstract}
ABSTRAK
Penelitian ini bertujuan untuk mengetahui pengaruh model pembelajaran inquiry terhadap hasil belajar siswa pada materi pokok suhu, kalor dan perpindahan kalor serta melihat aktivitas siswa. Jenis penelitian ini adalah quasi eksperimen dengan two group pre-testt-posttest design. Populasi dalam penelitian ini adalah seluruh siswa kelas $\mathrm{X}$ semester II yang terdiri dari 8 kelas. Pengambilan sampel dilakukan dengan cara cluster random sampling yaitu kelas $\mathrm{X}_{4}$ sebagai kelas eksperimen dan kelas $\mathrm{X}_{2}$ sebagai kelas kontrol. Instrumen yang digunakan yaitu tes hasil belajar sebanyak 8 soal dalam bentuk uraian. Berdasarkan analisis data dan uji hipotesis diperoleh bahwa ada pengaruh model pembelajaran Inquiry terhadap hasil belajar siswa pada materi pokok suhu, kalor dan perpindahan kalor.
\end{abstract}

Kata Kunci : Model Pembelajaran Inquiry, Hasil Belajar, Aktivitas

\begin{abstract}
The objective of this research was to know the effect of Inquiiry learning model toward learning outcomes of students in the subject matter of termperature, heat and heat movement and to see the activity of students. This research is a quasi experimental with two group pretest-posttest design. The population is the entire second semester of tenth grade students consisting of 8 class. Sampling was done by cluster random sampling that is class $X_{4}$ as the experimental class and class $X_{2}$ as the control class. The instrument used in test as many as 8 questions in the form of essay test. Based on data analysis and hypothesis testing showed that there is effect of Inquiry Learning model on learning outcomes of student in the subject matter of termperature, heat and heat movement.
\end{abstract}

Keywords :Inquiry learning, Learning outcomes, activity 


\section{PENDAHULUAN}

Peranan seorang guru sangat diutamakan dalam memajukan pendidikan yang nantinya dapat berpengaruh pada kualitas siswa. Sebagai perancang atau perencana pembelajaran, seorang guru diharapkan mampu merancang pembelajaran agar proses pembelajaran dapat berjalan secara efektif dan efisien. Untuk itu seorang guru dituntut untuk memiliki pengetahuan yang cukup luas sebagai dasar untuk merancang kegiatan pembelajaran dengan memilih media pembelajaran, merumuskan tujuan, memilih bahan, memilih metode serta mengevaluasi kegiatan pembelajaran. Hal ini berarti berhasil tidaknya tujuan pendidikan bergantung pada bagaimana proses belajar yang dialami oleh siswa sebagai peseta didik dan guru sebagai tenaga pendidik yang tidak hanya berupaya mengusai materi pembelajaran namun juga mengetahui bagaimana cara materi itu disampaikan dan bagaimana pula karakteristik siswa yang menerima materi pelajaran tersebut.

Dalam Giancoli (2001:2) disimpulkan bahwa " sains adalah suatu aktivitas kreatif yang dalam banyak hal menyerupai aktivitas kreatif pikiran manusia". Pada dasarnya mata pelajaran Fisika adalah satu cabang sains yang dalam mempelajarinya

pembuktian konsep dengan eksperimen dan mengaitkannya dengan kehidupan nyata. Oleh sebab itu, diperlukan cara pembelajaran yang dapat menyiapkan peserta didik untuk mampu berpikir logis, kritis, serta dapat berargumentasi dengan benar. Untuk itu guru perlu melaksanakan pembelajaran yang efektif dan efisien untuk memahami setiap materi pelajaran.

Berdasarkan pengamatan peneliti sewaktu melaksanakan Program Pengalaman Lapangan Terpadu (PPLT) banyak sekali siswa yang menyatakan bahwa pelajaran fisika merupakan pelajaran yang sulit untuk dipahami oleh siswa dan membosankan. Pembelajaran disekolah masih bersifat verbal, siswa tampak pasif dan menerima pengetahuan sesuai dengan apa yang diberikan oleh guru, proses belajar mengajar yang dilakukan masih berpusat pada guru. Pemilihan strategi pembelajaran yang bersifat tradisional tanpa memberikan kesempatan kepada siswa untuk melibatkan diri dalam membuktikan teori dan konsep fisika secara nyata. Saat guru memberi kesempatan untuk bertanya atau menjawab siswa hanya diam karena mereka bingung apa yang harus ditanyakan dan dijawab.

Salah satu mata pelajaran yang selalu memiliki nilai rendah dan paling ditakuti siswa adalah mata pelajaran fisika. Kenyataan ini sesuai dengan hasil studi pendahuluan peneliti dengan melakukan wawancara kepada salah seorang guru fisika SMA Negeri 5 Medan, dari 43 orang siswa yang diobservasi, hanya 4 orang yang menyukai pelajaran Fisika dan hanya 2 orang siswa yang menganggap Fisika itu mudah dan menyenangkan. Hasil observasi diperoleh data hasil belajar fisika siswa yang pada umumnya masih rendah yaitu rata-rata 50 sedangkan Kriteria Ketuntasan Minimal (KKM) yang akan dicapai adalah 70 , sehingga dapat dikatakan nilai rata-rata siswa tidak mencapai kriteria yang diharapkan. Hal ini disebabkan karena siswa 
menganggap pelajaran fisika kesimpulan dari permasalahan yang merupakan pelajaran yang sulit, diberikan, dengan demikian, model membosankan, kurangnya pemahaman siswa dan penguasaan materi pelajaran serta kesalahan konsepsi pada materi pelajaran sehingga siswa sulit memecahkan soal.

Untuk itu perlu diterapkan model pembelajaran yang dapat membantah semua anggapan siswa tersebut dan merancang pembelajaran yang berpusat pada siswa. Dilihat dari segi kepuasan secara emosional, suatu hasil yang ditemukan sendiri, nilai kepuasannya lebih tinggi dibandingkan dengan hasil pemberian. Bila dikaitkan dengan pembelajaran, hasil pembelajaran yang ditemukan siswa sendiri akan bersifat lebih tahan lama diingat oleh siswa dibandingkan dengan pengetahuan yang sepenuhnya merupakan pemberian daari guru. Salah satu usaha yang dilakukan agar siswa dapat memahami apa yang dipelajarinya adalah dengan membimbing siswa untuk menggali pengetahuannya sendiri yang diperoleh berdasarkan pengalaman sehari-hari. Usaha tersebut dapat diwujudkan dengan penggunaan model pembelajaran inquiry.

Model pembelajaran inquiry adalah rangkaian kegiatan belajar yang melibatkan secara maksimal seluruh kemampuan siswa untuk mencari dan menyelidiki secara sistematis, kritis, logis,, analitis sehingga siswa dapat merumuskan sendiri penemuannya dengan percaya diri. Diharapkan dengan model pembelajaran inquiry ini, siswa tidak hanya mendengar konsep-konsep fisika saja, melainkan juga dapat memikirkan, mengumpulkan data melalui percobaan, membuat

pembelajaran inquiry mendukung pembelajaran yang berpusat pada siswa (student center-approaches) yang menjadikan siswa berperan aktif dalam pembelajaran.

Berdasarkan hasil penelitian terdahulu yang dilakukan Yeni Evalina (2012) dengan judul "Perbedaan Hasil Belajar Siswa Menggunakan Model Pembelajaran Inquiry dengan Konvensional Pada Materi Pokok Zat Dan Wujudnya di Kelas VII SMP BRIGJEND KATAMSO Medan Sunggal Semester Ganjil T.P 2011/2012", mengatakan bahwa, "adanya pengaruh penggunaan model pembelajaran inquiry terhadap prestasi belajar siswa, dapat ditunjukkan dari nilai postesnya 73,88 pada kelas eksperimen dan pada pembelajaran konvensional diperoleh nilai rata-rata 68,89. Dari penelitian Tiarmaida (2014) dengan judul "Pengaruh Model Pembelajaran Inquiry Terhadap Hasil Belajar Siswa Pada Materi Pokok Listrik Dinamis di Kelas X Semester II SMA Negeri 8 Medan T.P 2013/2014", mengatakan bahwa, "adanya pengaruh penggunaan model pembelajaran inquiry terhadap prestasi belajar siswa, dapat ditunjukkan dari nilai postesnya 71,66 pada kelas eksperimen dan pada pembelajaran konvensional diperoleh nilai rata-rata 64,5 .

Berdasarkan uraian masalah di atas, maka penulis tertarik untuk melakukan penelitian dengan judul: "Pengaruh Model Pembelajaran Inquiry Terhadap Hasil Belajar Siswa pada Materi Pokok Suhu Kalor dan Perpindahan Kalor di Kelas X Semester Genap SMA Negeri 5 Medan T.P 2014/2015". 


\section{METODE PENELITIAN}

Penelitian ini dilaksanakan di SMA Negeri 5 Medan pada siswa kelas X. Waktu penelitian dilaksanakan pada Semester II Tahun Pembelajaran 2014/2015.

Populasi dalam penelitian ini adalah seluruh siswa kelas X SMA Negeri 5 Medan T.P 2014/2015 berjumlah 8 kelas. Pada penelitian ini sampel terdiri dari dua kelas yang dipilih dengan teknik cluster random sampling yaitu kelas $\mathrm{X}_{4}$ sebagai kelas eksperimen yang menerapkan model pembelajaran inquiry dan kelas $\mathrm{X}_{2}$ sebagai kelas kontrol dengan menerapkan model pembelajaran konvensional.

Jenis penelitian yang digunakan dalam penelitian ini adalah quasi eksperiment. Desain penelitian yang digunakan yaitu Two group pre testpos test design seperti yang terlihat pada tabel 1 berikut ini.

Tabel 1. Two group pretest-postest design

\begin{tabular}{|l|c|c|c|}
\hline Kelas & $\begin{array}{c}\text { Tes awal } \\
\left(\mathrm{T}_{1}\right)\end{array}$ & $\begin{array}{c}\text { Perlakuan } \\
(\mathrm{X})\end{array}$ & $\begin{array}{c}\text { Tes } \\
\text { Akhir } \\
\left(\mathrm{T}_{2}\right)\end{array}$ \\
\hline Eks & $\mathrm{T}_{1}$ & $\mathrm{X}_{1}$ & $\mathrm{~T}_{2}$ \\
\hline Kontrol & $\mathrm{T}_{1}$ & $\mathrm{X}_{2}$ & $\mathrm{~T}_{2}$ \\
\hline
\end{tabular}

Keterangan :

$\mathrm{T}_{1} \quad$ : Tes pertama (pre-test)

$\mathrm{T}_{2}:$ Tes akhir (pos-test)

$\mathrm{X}_{1}$ : Perlakuan pada kelas eksperimen dengan menggunakan model pembelajaran inquiry

$\mathrm{X}_{2}$ : Perlakuan pada kelas kontrol dengan menggunakan pembelajaran konvensional

Instrumen yang digunakan dalam penelitian ini adalah tes hasil hasil belajar sebanyak 8 soal uraian, yang akan diberikan pada pre-test dan post-test.

Pengujian hipotesis ada dua cara yaitu: uji $t$ dua pihak untuk mengetahui kemampuan awal siswa pada kedua kelas yaitu pada kelas eksperimen dan kelas kontrol.

Kriteria pengujian adalah :

terima $\mathrm{H}_{\mathrm{O}}$ jika $\quad-t_{1-\frac{1}{2} \alpha}<t<t_{1-\frac{1}{2} \alpha}$

dimana $t_{1-\frac{1}{2} \alpha}$ didapat dari daftar distribusi t dengan $d k=\mathrm{n}_{1}+\mathrm{n}_{2}-2$ dan $\alpha=0,05$. Untuk harga $t$ lainnya $H_{O}$ ditolak.

Kedua adalah uji t satu pihak yaitu untuk melihat pengaruh dari model pembelajaran inquiry terhadap hasil belajar siswa.

Kriteria pengujian adalah :

terima $\mathrm{H}_{\mathrm{O}}$ jika $-t_{(1-\alpha)}<t<t_{(1-\alpha)}$ dimana $t_{(1-\alpha)}$ didapat dari daftar distribusi t dengan $\mathrm{dk}=\mathrm{n}_{1}+\mathrm{n}_{2}-2$ dan $\alpha=0,05$. Untuk harga $t$ lainnya $H_{0}$ ditolak.

\section{HASIL DAN PEMBAHASAN}

\section{Hasil Penelitian}

Dibawah ini adalah tabel-tabel dari nilai rata-rata, uji normalitas, uji homogenitas dari pretes dan postes kedua kelas secara ringkas.

Tabel 2. Nilai Rata-Rata Pretes dan Postes Kedua Kelas

\begin{tabular}{|c|c|c|}
\hline \multirow{2}{*}{ Kelas } & \multicolumn{2}{|c|}{ Rata-Rata } \\
\cline { 2 - 3 } & Pretes & Postes \\
\hline Eksperimen & 36,66 & 56,48 \\
\hline Kontrol & 33,72 & 52,54 \\
\hline
\end{tabular}

Tabel diatas menunjukkan bahwa nilai rata-rata pretes pada kedua kelas hampir sama, sedangkan setelah diberikan perlakuan diperoleh bahwa nilai rata-rata postes kelas eksperimen lebih tinggi dibandingkan 
di kelas kontrol. Hasil diatas tampak perbedaan hasil belajar sebesar 3,94 antara kelas eksperimen dan kelas kontrol.

Hasil uji $\mathrm{t}$ dua pihak dengan menggunakan data pretes diperoleh harga $t_{\text {hitung }}<t_{\text {tabel }}$ yaitu $1,36<1,99$, berarti $\mathrm{H}_{\mathrm{o}}$ diterima yaitu kemampuan awal siswa pada kelas eksperimen sama dengan kemampuan awal siswa pada kelas kontrol. Untuk uji t satu pihak yang menggunakan data postes diperoleh bahwa $t_{\text {hitung }}>t_{\text {tabel }}$ yaitu $1,8808>1,6642$ pada taraf signifikansi 0,05 berada pada dk 60 dan $\mathrm{dk} 120$. Dapat diambil kesimpulan bahwa hipotesis $\mathrm{H}_{\mathrm{a}}$ diterima yaitu ada pengaruh model pembelajaran inquiry terhadap hasil belajar siswa pada materi pokok Suhu Kalor dan Perpindahan Kalor di Kelas X semester II SMA Negeri 5 Medan T.P 2014/2015.

Berdasarkan hasil observasi aktivitas siswa baik dikelas eksperimen maupun dikelas kontrol diperoleh bahwa nilai rata-rata aktivitas dari pertemuan I sampai pertemuan III dikelas eksperimen yaitu 70,17 dengan kategori aktif dan nilai rata-rata aktivitas pertemuan I sampai pertemuan III dikelas kontrol 59,71 dengan kategori cukup aktif.

\section{Pembahasan}

Hasil penelitian menunjukkan bahwa ada pengaruh model pembelajaran inquiry terhadap hasil belajar siswa pada materi pokok Suhu, Kalor dan Perpindahan Kalor di Kelas X Semester II SMA Negeri 5 Medan T.P. 2014/2015, ditunjukkan dengan nilai rata-rata postes di kelas eksperimen yaitu 56,48 dan nilai ratarata postes di kelas kontrol yaitu 52,54 .

Hal ini didukung karena model pembelajaran inquiry menuntut siswa untuk lebih aktif dalam pembelajaran dan mengajak siswa untuk menyelidiki secara langsung mengenai masalah yang telah disampaikan pada awal pembelajaran. Model pembelajaran ini menghadapkan siswa pada situasi yang membingungkan sehingga siswa tergugah untuk mencari tahu sendiri jawaban dari permasalahan yang ada (Joyce, 2011).

Model pembelajaran inquiry terdiri dari 5 tahapan yaitu : menghadapkan siswa pada masalah, mengumpulkan data verifikasi yaitu dengan mendorong siswa untuk mengajukan pertanyaan atas permasalahan yang telah dipaparkan dan dijawab dengan "ya" atau "tidak", kemudian mengumpulkan data melalui eksperimen, selanjutnya mengolah data hasil eksperimen, dan tahap yang terakhir adalah menganalisis proses inkuiri.

Pada tahap pertama, siswa dihadapkan pada masalah dengan seperti memperlihatkan visualisasi berupa video kepada siswa, mendemonstrasikan langsung suatu percobaan di depan kelas, serta langsung memberikan pertanyaan berupa masalah yang akan diselidiki, kemudian siswa diminta untuk memperhatikan dengan seksama. Namun pada pertemuan I hanya sedikit siswa yang memberikan jawaban namun belum disertai alasan yang tepat. Pada pertemuan ke II dan III, ada peningkatan siswa yang memberikan jawaban dan memberikan alasannya dengan tepat. Pada tahap kedua, siswa didorong untuk mengajukan pertanyaan mengenai masalah yang sudah dipaparkan. Tetapi pada awalnya siswa masih kurang mengerti untuk mengajukan pertanyaan yang harus dapat dijawab dengan "ya" ataupun 
"tidak". Pada pertemuan selanjutnya, siswa semakin terlatih untuk membuat pertanyaan seperti yang diharapkan. Kemudian siswa dibentuk kedalam 5-6 orang dalam satu kelompok dan siswa diminta untuk duduk bersama teman-teman sekelompoknya. Selanjutnya membagikan LKS dan meminta siswa untuk memaparkan hipotesis mereka mengenai masalah yang sudah ada didalam LKS tersebut sebelum dilakukan eksperimen untuk membuktikan hipotesis mereka. Setelah itu peneliti membagikan alat dan bahan kepada masing-masing kelompok dan setiap kelompok diminta melakukan percobaan sesuai dengan LKS yang telah dibagikan. Pada pertemuan I, siswa masih kurang terbiasa dalam melakukan eksperimen sehingga siswa membutuhkan banyak bimbingan dalam melakukan praktikum. Tetapi pada pertemuan selanjutnya siswa mulai terbiasa melakukan eksperimen dan kegiatan percobaan menjadi lebih terarah serta siswa semakin memahami tugas yang harus mereka kerjakan seperti yang tertera pada LKS. Setelah memperoleh data hasil eksperimen, peneliti membimbing siswa untuk mengolah dan menganalisis data hasil percobaan dan menarik kesimpulan dari eksperimen yang telah mereka lakukan. Pada tahap terakhir, siswa mempresentasikan hasil diskusi yang telah mereka lakukan didepan kelas.

Nilai rata-rata postes pada kelas eksperimen tergolong dalam kategori tidak tuntas dikarenakan belum melewati batas KKM yaitu 75 . Namun jika melihat dari nilai masing-masing siswa diperoleh 13 orang siswa dari seluruh jumlah siswa (39 orang) atau 33,33\% siswa yang mencapai KKM dan 26 atau
$66,67 \%$ siswa yang belum mencapai KKM. Sedangkan pada kelas kontrol, dilihat dari masing-masing siswa diperoleh 3 orang siswa dari seluruh jumlah siswa (34 orang) atau 8,82\% siswa yang mencapai KKM dan 31 atau $91,17 \%$ siswa yang belum mencapai KKM. Dari hasil perhitungan tersebut diperoleh bahwa lebih banyak siswa yang memperoleh nilai diatas KKM adalah siswa pada kelas eksperimen dibanding pada kelas kontrol. Jika dibandingkan dari masing-masing kelas, yaitu pada nilai rata-rata pretes dan postes maka kelas eksperimen peningkatannya lebih tinggi dibandingkan kelas kontrol yaitu sebesar 37,61 sedangkan di kelas kontrol peningkatannya sebesar 29,41 .

Aktivitas diamati oleh observer pada kelas eksperimen maupun kelas kontrol. Aktivitas yang diamati yaitu: visual activities, listening activities, oral activities, writing activities, motor activities, mental activities, dan emotional activities. Rata-rata aktivitas siswa pada kelas eksperimen pada pertemuan I adalah 62,52 dengan kriteria penilaian aktif. Pada pertemuan I, siswa masih bingung dengan model pembelajaran yang diterapkan sehingga kegiatan pembelajaran kurang berjalan dengan baik. Pada pertemuan II diperoleh rata-rata aktivitas siswa sebesar 71,86 dan masih dalam kriteria aktif. Terdapat peningkatan aktivitas sebesar 9,34\%. Pada pertemuan II, siswa mulai mengerti dengan pembelajaran yang diterapkan dan siswa semakin aktif dalam bertanya dan memaparkan pendapat. Pada pertemuan III, diperoleh rata-rata aktivitas sebesar 76,13 dengan kriteria aktif. Diperoleh peningkatan aktivitas sebesar 4,27\%. Maka dari 
hasil perhitungan rata-rata aktivitas dari pertemuan I sampai pertemuan III pada kelas eksperimen yaitu 70,17 dengan kriteria penilaian aktif.

Pada kelas kontrol juga diamati aktivitas siswa selama pembelajaran. Pada pertemuan I, diperoleh rata-rata aktivitas siswa sebesar 56,86 dengan kategori cukup aktif. Kemudian pada pertemuan II diperoleh sebesar 60,01 dengan kriteria aktif. Terdapat peningkatan rata-rata aktivitas sebesar $3,15 \%$ dan pada pertemuan III diperoleh rata-rata aktivitas sebesar 62,25 dengan aktif. Peningkatan aktivitas dari pertemuan III dan II diperoleh sebesar $0,76 \%$. Namun peningkatan aktivitas pada kelas kontrol tidak sebesar peningkatan aktivitas di kelas eksperimen. Salah satu aktivitas yang paling membedakan kelas kontrol dan kelas eksperimen yaitu pada kelas kontrol tidak dilakukannya percobaan. Pada kelas kontrol tidak melibatkan siswa secara langsung dalam penyelidikan ilmiah. Diperoleh rata-rata aktivitas siswa di kelas kontrol dari pertemuan I sampai III yaitu sebesar 59,71 dengan kriteria cukup aktif.

Beberapa penelitian yang relevan dengan penelitian ini seperti dalam Harahap (2013) mengenai model pembelajaran inquiry dapat meningkatkan hasil belajar siswa, dimana diperoleh nilai rata-rata pretes di kelas eksperimen dan kelas kontrol adalah 36,66 dan 33,72. Setelah diberi perlakuan, diperoleh rata-rata nilai postes pada kelas eksperimen dan kelas kontrol adalah 56,48 dan 52,54. Begitu juga dengan aktivitas dengan menerapkan model pembelajaran inquiry, dimana terdapat peningkatan aktivitas yaitu 51,33 pada pertemuan I dan 70,33 pada pertemuan kedua. Maka disimpulkan bahwa ada pengaruh yang signifikan model pembelajaran inquiry terhadap hasil belajar siswa. Begitu juga pada penelitian Sirait (2012), diperoleh nilai rata-rata pretes 4,29 dan nilai rata-rata postes 6,29 untuk kelas eksperimen dan nilai rata-rata pretes 4,03 dan nilai ratarata postes 5,64 untuk kelas kontrol. Dapat dilihat bahwa peningkatan hasil belajar lebih tinggi dikelas eksperimen yaitu dengan penerapan model pembelajaran inquiry. Demikian juga dengan rata-rata aktivitas yang diperoleh yaitu sebesar 67,38 dengan kategori aktif.

Meskipun model pembelajaran inquiry dapat meningkatkan hasil belajar dan aktivitas siswa yang lebih baik dibanding pembelajaran konvensional, namun selama peneliti melaksanakannya masih ada kesulitan-kesulitan yang dihadapi diantaranya yaitu masih adanya siswa yang tidak serius di dalam kelompok pada saat praktikum. Untuk mengatasi hal ini, sebaiknya upaya yang dilakukan adalah lebih memperhatikan setiap kelompok atau setiap individu didalam kelompok serta membentuk 3-4 orang setiap kelompok agar pembelajaran dapat berlangsung lebih efektif dan efisien. Dengan jumlah ini maka akan memungkinkan setiap siswa dalam kelompok dapat bekerja sama dan semuanya dapat ambil bagian dalam melakukan praktikum. Kesulitan yang lain adalah masih kurang maksimalnya pengawasan saat dilakukannya pembelajaran didalam kelas, terkhusus ketika dilakukannya praktikum. Untuk mengatasi hal ini, sebaiknya perlu ditambah jumlah observer, agar pengawasan ketika dilaksanakannya pembelajaran lebih maksimal, karena setiap observer sudah diberikan tugas untuk 
mengawasi satu atau dua kelompok saja. Sehingga pembelajaran dapat berlangsung dengan baik.

\section{KESIMPULAN DAN SARAN Kesimpulan}

Berdasarkan hasil penelitian yang diperoleh dari hasil analisa data dan pengujian hipotesis maka dapat disimpulkan bahwa ada pengaruh model pembelajaran inquiry terhadap hasil belajar siswa pada materi pokok Suhu, Kalor dan Perpindahan Kalor di Kelas X Semester II SMA Negeri 5 Medan T.P. 2014/2015. Dimana diperoleh nilai postes dikelas eksperimen yaitu 70,94 dan dikelas kontrol yaitu 62,35. Rata-rata aktivitas dari pertemuan I sampai pertemuan III pada kelas eksperimen adalah 70,17 dengan kriteria penilaian aktif dan rata-rata aktivitas pada kelas kontrol adalah 59,71 dengan kriteria penilaian cukup aktif.

\section{Saran}

Berdasarkan penelitian yang telah dilakukan maka beberapa hal yang disarankan untuk peneliti lebih lanjut membuat perencanaan yang lebih baik pada pengorganisasian kelompok, sebaiknya jumlah siswa dalam setiap kelompok cukup 3 - 4 orang saja supaya setiap anggota kelompok tersebut aktif dalam kegiatan praktikum. Kemudian agar menambah jumlah observer, agar ketika dilaksanakannya pembelajaran pengawasan lebih maksimal, karena setiap observer sudah mendapatkan tugas untuk mengawasi satu atau dua kelompok saja sehingga pembelajaran dapat berlangsung kondusif.

\section{DAFTAR PUSTAKA}

Giancoli. 2001. Fisika Edisi Kelima Jilid 1. Jakarta : Erlangga
Joice, B.(2011). Models of Teaching. Yogyakarta: Pustaka Pelajar.

Sari, S.R. 2013. Pengaruh Model Pembelajaran Inquiry Terhadap Hasil Belajar Siswa Pada Materi Pokok Listrik Dinamis Di Kelas $X$ Semester II SMA Negeri 16 Medan T.P 2012/2013. FMIPA UNIMED

Sudjana. 2005. Metode Statistika. Bandung: Tarsito

Tarigan,Y.E. 2012. Perbedaan Hasil Belajar Siswa Menggunakan Model Pembelajaran Inquiry dengan Konvensional Pada Materi Pokok Zat dan Wujudnya di Kelas VII SMP BRIGJEND KATAMSO Medan Sunggal Semester Ganjil Tahun Ajaran 2011/2012. FMIPA UNIMED

Tiarmaida. 2014. Pengaruh Model Pembelajaran Inquiry Terhadap Hasil Belajar Siswa Pada Materi Pokok Listrik Dinamis di Kelas $X$ Semester II SMA Negeri 8 Medan T.P 2013/2014. FMIPA UNIMED 